\title{
Seedling roots and forest floor: Misplaced and neglected aspects of British Columbia's reforestation effort?
}

\author{
by A.C. Balisky ${ }^{1}$, P. Salonius ${ }^{2}$, C. Walli ${ }^{3}$ and D. Brinkman ${ }^{3}$
}

Concepts of planted seedling root morphology and root location are discussed in the context of reforestation in British Columbia. Comparison of root form and location between natural and planted seedlings reveals profound differences. Unnatural root morphology and delayed development of nursery-produced rooting systems, coupled with current planting techniques that emphasize vertical orientation of roots in mineral soil horizons, may exacerbate harsh microenvironmental site conditions. Inappropriate root systems may inhibit optimal seedling function and compromise long-term stand stability. The forest floor is seen as an appropriate rooting medium to which planted seedlings should be allowed ready access. A change in the biological geometry (direction and depth of root development) of the planted root system may enhance survival, establishment, and growth. The promotion of more natural, lateral, surface rooting at the organic/mineral soil interface is proposed. Site-specific root morphologies and planting strategies may be required.

Key words: regeneration silviculture, tree-planting, target seedling stocktype, root egress, root morphology, root location, forest floor, soil temperature, soil moisture, frost heaving, soil nutrients, mycorrhizae, site preparation, alternative stocktypes
Les concepts portant sur la morphologie des racines des semis plantés et de la disposition des racines sont abordés dans le contexte du reboisement en Colombie-Britannique. La comparaison de la forme des racines et de leur disposition entre les semis naturels et les semis plantés révèle des différences significatives. La morphologie artificielle et le développement retardé du système racinaire chez les semis produits en pépinière, en plus des techniques actuelles de plantation qui mettent l'accent sur l'orientation verticale des racines dans les horizons du sol minéral, peuvent devenir des éléments contraignants sous des conditions difficiles rencontrées au niveau microenvironmental du site. Un système racinaire inadéquat peut restreindre le développement optimal du semis et compromettre la stabilité du peuplement à long terme. Le sol forestier est perçu comme étant un médium d'enracinement approprié auquel les semis plantés devraient avoir libre accès. Une modification de la géométrie biologique (direction et profondeur du développement des racines) du système racinaire des semis plantés pourrait accrô̂tre la survie, l'établissement et la croissance. La promotion d'un système racinaire plus naturel, se développant latéralement et en surface au niveau de l'interface du sol organique et du sol minéral est suggérée. Une morphologie des racines spécifiques au site à reboiser ainsi que des stratégie de plantation pourraient être requises.

Mots clés: sylviculture de régénération, plantation d'arbres, type de semis optimal, émersion des racines, morphologie racinaire, localisation des racines, sol forestier, température du sol, humidité du sol, déchaussement par le gel, éléments nutritifs du sol, mycorhizes, préparation du site, types de semis de rechange

\section{Introduction}

Increased timber harvesting has resulted in an unprecedented reforestation program in British Columbia with the 3 billionth tree planted in June 1993. Legislation now requires "free-growing" plantations to be established on all cutovers in the province. A "target seedling" concept (Rose et al. 1990) has evolved to facilitate a site-specific approach to reforestation. However, various environmental microsite conditions impacting on the planted seedling seriously diminish potential growth. Some microenvironmental factors affect the aerial portion of the seedling. Of equal physiological significance is the soil regime and the biological geometry of the seedling root system. Current planting guidelines in British Columbia may inhibit optimal seedling function on numerous outplanting sites (Butt 1986, 1990; Binder et al. 1987) and compromise long-term stand stability of pines (Burdett et al. 1986). Development work on seedling root morphology and rooting location may produce new sitespecific approaches based on physiological and ecological evidence.

In this paper, several objections to current tree-planting procedures which are based on the unnatural root geometry of

\footnotetext{
${ }^{1}$ Fletcher Challenge Canada Limited, Mackenzie Woodlands, Mackenzie, British Columbia.

${ }^{2}$ Canadian Forestry Service - Maritimes Region, Fredericton, New Brunswick.

${ }^{3}$ Brinkman and Associates Reforestation Ltd., New Westminister, British Columbia.
}

styroblock stocktypes are specified. Several effective stocktype and planting alternatives that allow for more natural root growth in more natural rooting substrates are suggested.

\section{The Existing Situation}

The most common soil orders associated with the commercial conifers in British Columbia have some accumulation of surface organic matter. This organic material and underlying mineral soil offer distinctly different rooting environments. Current planting procedure is detailed in Turner (1990). Current guidelines specify that roots are to be firmly planted in mineral soil in a vertical orientation after the forest floor has either been removed, inverted, or mixed.

Current annual nursery production is over 200 million with $>30$ different sizes and combinations of styroblock and bareroot stocktypes (Scagel et al. 1992). Early root growth of containerized pine seedlings, and other species to a lesser extent, is restricted to elongation of lateral roots that have grown down the container wall to the tip of the root plug (Burdett 1978; McMinn 1978). Root growth of bareroot and transplant stock is also dictated by the planting location of active root tips. Root tips will be predominantly in the lower portion of the planting hole if planting meets current specifications. This is in contrast to natural conifer germinants which develop an extensive system of lateral roots that colonize the nutrient-rich environment surrounding the organic/mineral soil interface (Eis 1978; Kimmins and Hawkes 1978; Strong and La Roi 1985). 

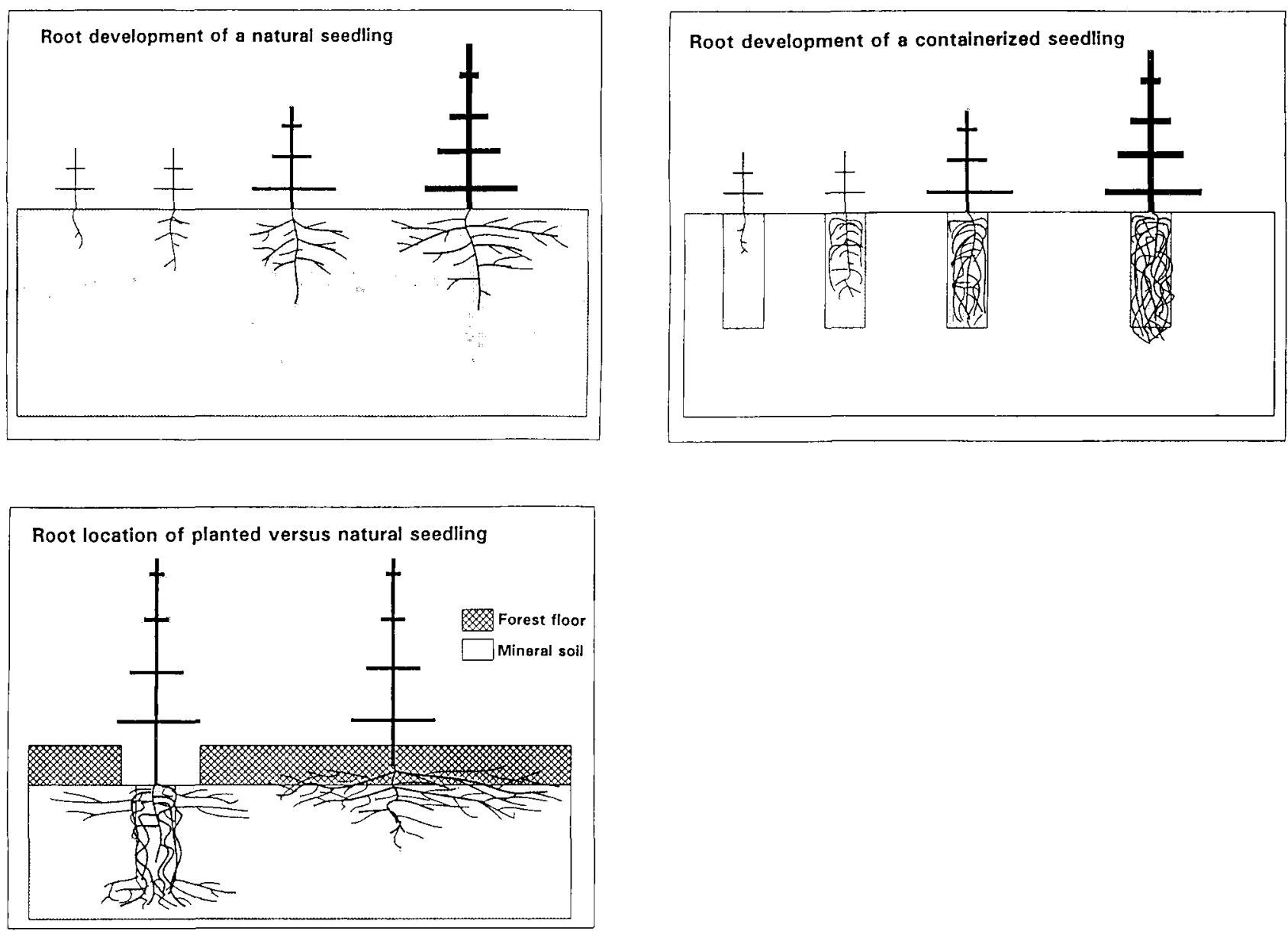

Figure 1. Root morphology differences between natural seedlings (top left) and container seedlings (top right). Natural seedlings with a predominantly lateral root system occurring adjacent to the organic/mineral soil interface (bottom right). Conventionally planted nursery seedlings (including bare root, container and transplant stocktypes) with a strongly vertical orientation within mineral soil horizons (bottom left).

The most important weakness of container-grown seedlings is the reorientation of primary support lateral roots from horizontal or oblique to vertical (Kinghorn 1978). The location of the root mass of the planted seedling in the soil profile differs dramatically (Fig. 1) from that of a natural seedling (Halter and Chanway 1993). Naturally established seedlings exhibit oblique, rapidly tapering, primary support roots (Eis 1974). Container stock shows severe primary support lateral root deformation caused by the constriction of container walls. Roots of natural seedlings are free to explore soils at any depth. Root egress from the plug into the outplant soil is largely restricted to the bottom of the plug in the first season of planting due to the direction of growing root tips towards the drain hole in walled containers during nursery rearing. Growth of secondary and tertiary laterals, arising from the planted root system, takes place later; these rope-like or "spaghetti" lateral roots tend to grow parallel to the soil surface (Eis 1978). These nontapering roots do not provide the buttressing support offered by primary support laterals. Some species such as the spruces produce quite natural-looking root systems from adventitious roots that grow from the bottom of the stem of the seedling after planting. These roots have no relation to the root system developed in the nursery.
British Columbia Ministry of Forests guidelines for planting are contained in the Planting Quality Inspection Manual F.S. 704 (1990) which depicts a dozen possible planting faults for which planters may be financially penalized. Of the 12 faults, 10 relate directly to root placement infractions. Although nutrient and moisture availability is essential for seedling growth, microsites consisting of rotted wood or duff (forest floor) are considered inappropriate. While surficial, lateral root growth is ubiquitous among natural seedlings in boreal environments, shallow planting and placement of roots in a position other than vertical are not allowed. The guidelines produce a situation where roots are placed in mineral soil with the growing tips at the lowest and coldest location in the planting hole. Both root growth and water availability are controlled by soil temperature and mineral soils are consistently below optimum temperatures in the absence of radical treatment. Many forest companies follow the Planting Quality Inspection Manual.F.S. 704 guidelines, although increasingly foresters are independently developing ecosystem, site, and microsite treeplanting variations that recognize forest floor values.

Root growth of many boreal conifer seedlings becomes limited at soil temperatures below $8-12^{\circ} \mathrm{C}$ (Lopushinsky and Max 1990). Of several measured environmental variables, 


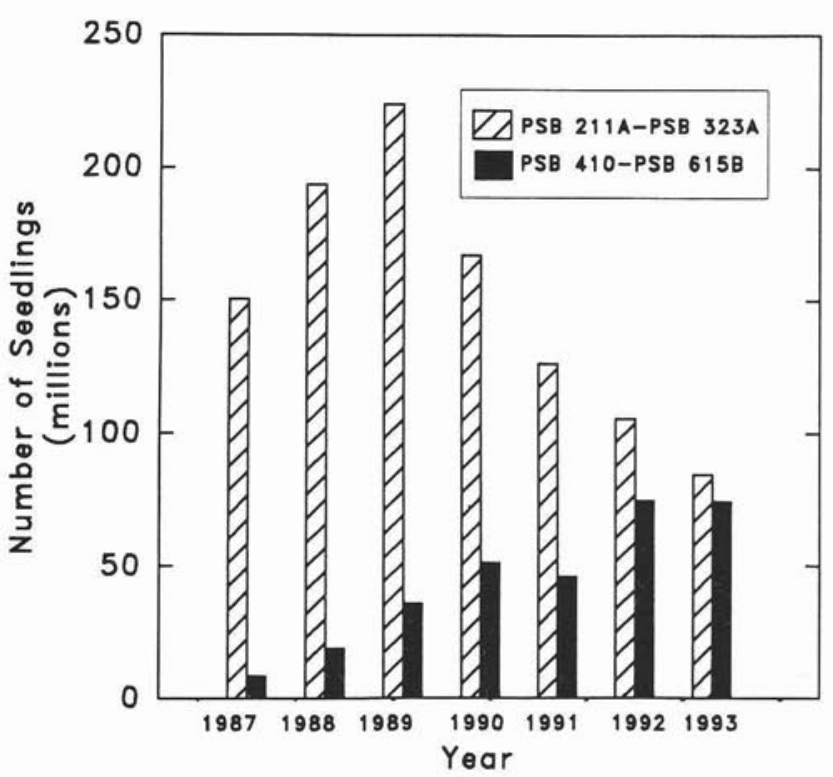

Figure 2. Trend in annual nursery production of small (PSB 211A - PSB 323A) and large (PSB 410 - PSB 615B) stocktypes in British Columbia between 1987-1993.

low soil temperature was shown to be the most important in controlling conifer seedling growth in a boreal environment (Brand and Janas 1988). Only the top few centimeters of the organic horizon in an undisturbed forest soil receive significant heat loading. An attenuation of heat energy is seen with increasing soil depth. Much effort is now being directed into protecting the forest floor during harvesting operations. Instead of working against naturally existing conditions, both ecological and economic considerations suggest working with and using the thermal properties of the forest floor by placing planted roots so they have ready access to the organic/mineral soil interface.

The large pores (low bulk density) of decomposing organic matter in organic horizons renders them less able to retain water (once free water has drained) than mineral soils; however, moisture is adequately available for seedling growth in the duff of some forest ecosystems. Moisture does not limit survival or growth of seedlings planted in the organic layer in the Interior Cedar Hemlock moist cool subzone (Heineman 1991). The shallow rooting characteristics of naturally established seedlings in subboreal/boreal climates suggest that there is adequate moisture generally available in the organic layer.

Frost heaving is affected by soil texture, structure and hydraulic conductivity. The large, non-capillary pores of organic materials impede the upward movement of water which is necessary for ice layer formation and subsequent frost heaving. Increasingly deeper placement of seedling roots in the soil profile to avoid frost heaving has been suggested (Stathers and Spittlehouse 1990), but this may only exacerbate the nutritional and temperature problems associated with mineral soils at greater depth.

Mycorrhizal fungi are essential to water and nutrient acquisition for most forest tree species. Harvey et al. (1987) found that the organic soil components supported virtually all the ectomycorrhizal root systems of naturally established seedlings. The

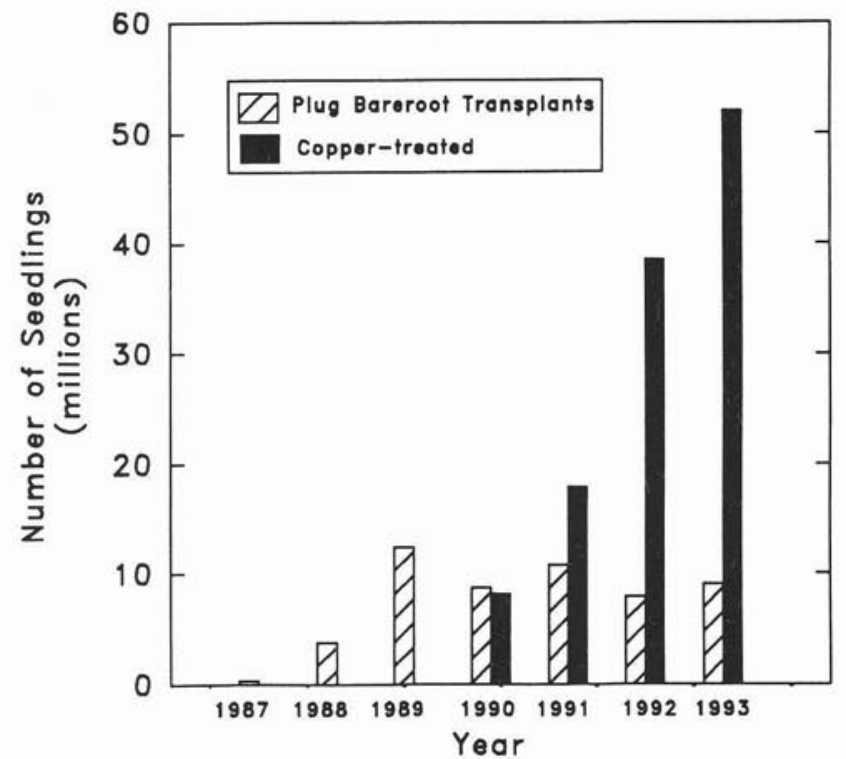

Figure 3. Trend in annual nursery production of transplant and coppertreated container seedlings in British Columbia between 1987 and 1993.

forest floor is the prime nutrient reservoir in the forest ecosystem (Gessel and Balci 1963). Placement of seedling root systems, with a full array of root growth options, such that they have ready access to this nutrient-rich zone would seem to be an essential practice.

In concert with existing planting guidelines which infer seedling roots should be planted into mineral soils in a vertical orientation, costly mechanical site preparation is now the most common solution for ameliorating poor soil conditions (Örlander et al. 1990). The physiological effectiveness of directing roots vertically into a progressively less favorable environment is suspect. Alternative root morphologies and planting strategies that mimic natural seedling growth will facilitate seedling establishment and growth and reduce regeneration costs. Problems with nursery-produced root morphologies have been well documented (van Eerden and Kinghorn 1978; Halter et al. 1993) and there has been concern for an adequate root architecture to provide sufficient stability for the mature tree (Grene 1978). Root excavations of Douglas-fir plantation trees by Scagel and Evans (1992) (Coastal Western Hemlock biogeoclimatic zone) and Newton and Cole (1991) (coastal Oregon) suggest that nursery-produced root deformities may be overcome 5 to 10 years after planting. Recent evidence from sites of lower productivity suggests this is not always the case (Halter and Chanway 1993: Halter et al. 1993). The objective in seedling culture should be to produce rooting systems that develop from nursery morphology towards a more natural root form on the planting site as quickly as possible.

\section{Styroblock Modifications}

There are presently physiological and morphological "target seedling specifications" for certain planting sites. There should also be appropriate species-specific root morphology goals that are to be attained within a reasonably short time after outplanting. There is renewed interest in the role of root morphology in terms 
of its effects on seedling establishment. There has been an increase in requests for stocktypes that promote more natural (lateral) root growth. New stocktypes should be capable of rapid, lateral rooting into mineral and organic soils, easily integrated into current nursery practice, not labor intensive or space consuming, and easily packaged and transported. A valid concern to nurserymen is the requirement for further capital investment and learning of new cultural and technical regimes that will be associated with industry requests for new, biologically superior stocktypes. Cost effectiveness considerations should include establishment success and growth rates when comparing new stocktypes with currently used ones. Efficiency of production and outplanting are important concerns; however, vigorous seedling growth upon outplanting is what foresters are chiefly interested in purchasing.

There is a distinct trend towards the use of larger diameter styroblock cavities (Fig. 2). The premise is than larger seedlings compete more vigorously for nutrients and light that smaller seedlings. Production of pine seedlings in copper-treated containers and plug transplants has also increased (Fig. 3). The use of root growth inhibitors to coat container walls was effective in promoting a more natural root form and improved growth in outplanted containerized seedlings (Hunt 1990). The copper-coated container system is an adaptation of British
Columbia's conventional nursery operations and outplanting technique and so it has blended easily into current practices. This method attempts to partially correct the problem of deformed roots but it falls short of addressing the deficiencies in rooting environment. Copper coating is toxic to roots and the technique cannot be used with some tree species (Burdett and Martin 1982). The "bottle brush" root form produced by copper coating (Dong and Burdett 1986) results in a very unstable root plug from which growing medium is easily lost during handling. As a compromise, copper treatment is applied in vertical bands such that half of the root plug is copper pruned while the rest of the roots have conventional vertical orientation to hold the plug together. Weak root plugs have a tendency to compress into the flat spade cut after tamping, thereby losing the necessary configuration that supports root egress on all sides (Brinkman, field observations).

Plug transplants offer seedlings with the most fibrous root mass possible in two growing seasons (Owston 1990). Although transplants may perform better than conventional containerized stock in some environments, they are expensive, space consuming, and labor intensive in the nursery. From a biological standpoint they fit the conventional paradigm of site preparation and mineral soil planting. Biologically, transplant stock may not be much of an improvement over containerized styroblock stock.

Table 1. Stocktype categories, associated container types, and description

\begin{tabular}{|c|c|c|c|}
\hline $\begin{array}{l}\text { Container } \\
\text { category }\end{array}$ & Description & $\begin{array}{l}\text { Container } \\
\text { type }\end{array}$ & Most widely used \\
\hline Bareroot & $\begin{array}{l}\text { Seedlings seeded and grown } \\
\text { in outdoor beds. Generally } \\
\text { grown from } 1 \text { to several years } \\
\text { before field planting. }\end{array}$ & & $\begin{array}{l}\text { Widely used throughout the world. Comprises } \\
\text { about } 20 \% \text { of Canada seedling production and } \\
\text { slightly more in the U.S.A. }\end{array}$ \\
\hline Hardwall & $\begin{array}{l}\text { Seedlings seeded and grown } \\
\text { in individual cavities. The } \\
\text { containers consist of a variety } \\
\text { of cavity size, shape, and } \\
\text { materials. Most are grown } \\
\text { in greenhouses, shelterhouses, } \\
\text { or outside compounds. }\end{array}$ & $\begin{array}{l}\text { Styroblock (styrofoam) } \\
\text { Multipot (plastic) } \\
\text { Spencer LeMaire (plastic) } \\
\text { Deepots (plastic) } \\
\text { Finnpots } \\
\text { Ray Leach (plastic) } \\
\text { Ensopots (plastic) } \\
\text { Nisula rolls } \\
\text { Panth (plastic) }\end{array}$ & $\begin{array}{l}\text { British Columbia } \\
\text { Canada-wide, Scandinavia } \\
\text { Ontario, Alberta - but general reduction in use } \\
\text { Mostly U.S.A. } \\
\text { Finland } \\
\text { Mostly U.S.A. } \\
\text { Finland } \\
\text { Being phased out } \\
\text { Scandinavia and Ontario }\end{array}$ \\
\hline Plug bareroot & Container grown then planted & Various & Worldwide, especially North America \\
\hline
\end{tabular}

transplant out in nursery beds and allowed to grow for 1 year before field planting.

Hardwall variants Most popular is copper-treated container varieties. The emphasis is to facilitate more natural rooting.

Softwall Soil held in "decomposable" paper or pressed peat which is planted with the seedling. Ideally the softwall decomposes and allows lateral root exit.

Slitwall Vertical openings in container wall to allow air pruning of plug sides.

Pillow

Meshwall Soil held in plastic film with root exit through base. Pillow is placed on top of ground.

Soil plug enclosed in fine mesh which allows for air pruning and rapid, lateral root exit.

Slitwall-meshwall Mesh plug held in slitwall container allows extraction before firm plug formation Multipot (plastic) Spencer LeMaire (plastic) eepots (plastic)

nnpots

(plastic)

Nisula rolls

Various

(n) Ontario

Membrane (plastic)

Copper-treated

Paperpot (paper)

Jiffypot (peat)

Plant system $80 / 90$

Plantek 63F

Peat pillow

Jiffy pellet (mesh)

Plant system 90-

Jiffy 96
Experimental in British Columbia British Columbia

Being phased out in Atlantic Canada and Ontario New Brunswick

Scandinavia

Scandinavia

Scandinavia

Nova Scotia, New Brunswick, Ontario 
Altering conventional planting techniques is currently widespread in industry. Foresters are now routinely disregarding the notion of duff or "red rot" as unacceptable planting medium and are permitting planters to simply plant through organic horizons such that the upper half of the plug is surrounded by warm nutrient-rich organic material and the lower portion of the plug is situated in the upper mineral soil horizons which provide a more consistent moisture supply. Lateral root development can proceed from the sides of the plug into organic material if viable root initials are present on the surface of the upper part of the plug. However, most new root growth from current styroblock plugs is from the terminal tip of the root plug and remains directed into nutrient-poor, cold, mineral soil. Spruces are intentionally planted so the lower part of the stem is below the soil surface to allow for the formation of adventitious roots after planting. These adventitious roots are often the ultimate structural support roots upon which planted spruce relies. For pines, which do not form adventitious roots (Selby and Seaby 1982), the use of copper-altered root systems is designed to keep primary support laterals from growing vertically down the container wall so as to allow lateral egress of these roots from the top of the plug when the influence of copper is removed at planting.

Other hardwall container experiments are proceeding where the whole plug is planted into deep organic layers (Heineman 1991). Forest industry stock requests have been made for transplant stock that has had the lower portion of the root mass chopped off so as to minimize the depth to which the growing root tips are planted (E. van Eerden, Pacific Regeneration
Technologies, Inc., pers. comm. with Balisky). These modified methods are gaining currency because they require minimal change to existing nursery facilities, and no loss of space or efficiency; their evolution suggests a growing appreciation of the more favorable growth conditions existing in or adjacent to the organic/mineral interface. Because of the limitations of working with hardwall container stocktypes, effective options are limited.

\section{Alternative Stocktypes}

Container evolution, particularly in eastern Canada and Scandinavia, has resulted in a diverse array of stocktypes (Table 1). Some of these stocktypes offer increased options in managing the root growth problems inherent to many container systems. A meshwall concept (Jiffy ${ }^{\mathrm{TM}}$ ) has gained increasing acceptance for silvicultural application in New Brunswick since 1983. Over the past 9 years, seedlings in meshwall plugs (which prune roots along the entire plug length by circulating air during nursery rearing) were found to develop more natural root systems shortly after outplanting. These root systems have tapered primary lateral support roots arising from the planted root plug and are the same age as the seedling; this is in contrast to adventitious roots on seedlings from conventional walled containers which are usually younger than the seedling due to production some time after planting. The premise upon which the meshwall concept is based is that at the time of outplanting, air pruned root tips should be positioned along the entire root plug and be free to rapidly explore

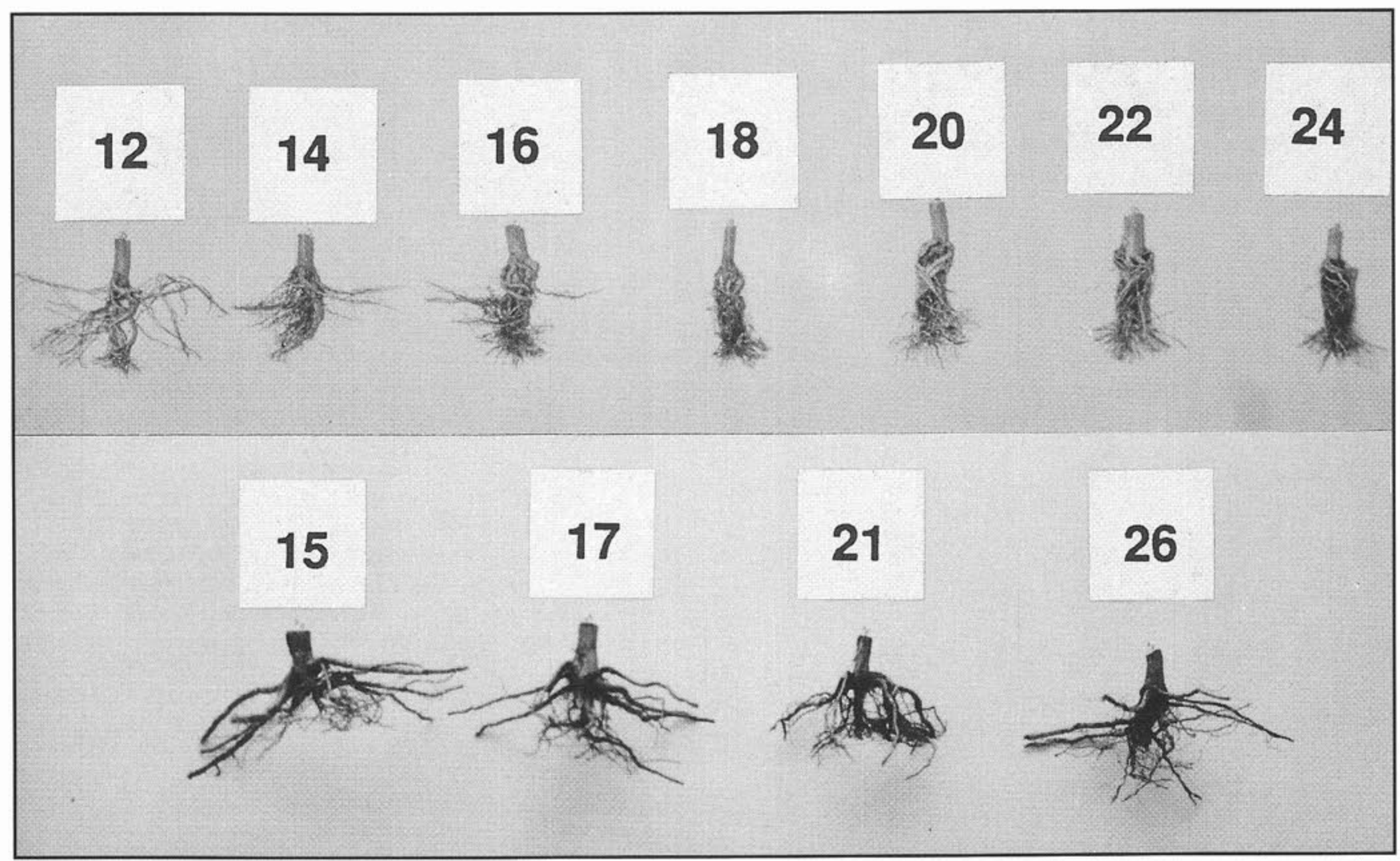

Figure 4. Roots of jack pine from a conventional walled cavity system (top row) and black spruce from a free standing mesh covered plug system (Jiffy ${ }^{\mathrm{TM}}$ ) (bottom row) after three field seasons. Extended roots were gathered together and cut approximately $5 \mathrm{~cm}$ below the bottom of rearing soil plug before washing. Numbers represent weeks growing in the nursery before outplanting (Salonius 1993, unpublished). 
organic and mineral soil horizons in any direction and thus access resources essential to growth (Burdett 1990) without first having to overcome "root-training" caused by container configuration. Meshwall stocktypes were studied for a number of years after planting with mesh intact or mesh carefully removed at planting. Outplanting trials in New Brunswick (Salonius unpubl. 1993) found that the very fragile netting does not inhibit root egress or growth. These studies have shown profound differences in root form of conifer seedlings planted as hardwall stocktypes and meshwall stocktypes. Excavated roots from a hardwall container variant with plastic membrane cavities were compared with those from a free-standing meshwall plug system (Jiffy ${ }^{\mathrm{TM}}$ ). Jack pine seedlings from plastic membrane cavities did not have adequate root development at 12 or 14 weeks from seeding to hold the soil together and allow for normal plug extraction; the plastic cavity was carefully cut off the fragile soil plug before planting. Seedlings grown in these cavities for 16 weeks and longer were extracted and planted in the normal manner. The mesh that holds the Jiffy plug together allowed black spruce seedlings to be easily planted at any time after seed germination. Photographs of fieldgrown seedling roots offer qualitative evidence of form and placement when excavation is delayed long enough for suberized roots to hold their orientation after the soil is washed away. The root form photographs (Fig. 4) show that jack pine seedlings with juvenile rooting systems in fragile plugs (which are not yet "root-bound") produced "natural" root form when outplanted. Longer nursery rearing in walled cavities results in the growing points of primary support roots being directed to the lower part of the root plug. Stability problems with pines tend to increase with increasing time that the seedlings have grown in container cavities (A. Lindström, Swedish University of Agricultural Sciences, pers. comm. with Salonius). Primary roots in the Jiffy ${ }^{\mathrm{TM}}$ system, in the nursery, grow out to the confining mesh and are air pruned; if irrigation is properly controlled, very little inter-rooting occurs between neighboring plugs. Upon outplanting, these air-pruned primary roots recommence growth and develop a "natural" root form, even after prolonged nursery rearing.

Direct seeding will produce natural root systems but this practice has met with success mainly with very large seeded species on sites that are comparatively unproductive and that offer little competitive pressure to seedlings. Sound biological alternatives are available for promoting natural rooting of planted seedlings. These options may include creative adjustments to existing hardwall stocktypes, changes in planting strategy, creation of new stocktypes, or adoption of an air-pruned root system. Use of a hardwall variant (copper-treated container stocktypes) and the meshwall (air-pruned) system appear to be the best solutions currently available.

\section{Conclusion}

Current research in regeneration silviculture has focused on the physiology of nursery-produced seedlings and the soil preparation required for establishment of these seedlings in the field. The evidence suggests that current seedling growth limitations are probably due more to suboptimal microsite conditions and exacerbated by the unnatural seedling root form produced by conventional containers and subsequent associated planting procedures. Perhaps further gains can be made by mimicking the rooting patterns of natural regeneration. Planted root systems should have as few artificial deforming constraints as possible, whether imposed by nursery culture or planting technique. It is time for a paradigm shift in nursery culture and outplanting methodology.

The varied soil and climatic conditions characteristic of British Columbia preclude use of any single outplanting system. A case has been presented for the reconsideration of the role of the forest floor as a viable rooting medium to which planted seedlings should be allowed immediate access when outplanted. A change in the geometry and subsequent growth patterns of planted root systems may facilitate improved plantation establishment and stability.

\section{Acknowledgements}

We would like to thank P. Burton, J. Worrall, T. Ballard, C. Chanway, R. Sutton and H. Benskin for helpful comments on the manuscript. We thank R. Bowden of the British Columbia Ministry of Forests (Silviculture Branch) for providing stock request data for British Columbia.

\section{References}

Binder, W.D., D.L. Spittlehouse and D.A. Draper. 1987. Post planting studies of the physiology of white spruce, 1984-1985. E.P. 966. Progress Report No. 5, British Columbia Ministry of Forests, Victoria, British Columbia.

Brand, D.G. and P.S. Janas. 1988. Growth and acclimation of planted white pine and white spruce seedlings in response to environmental conditions. Can. J. For. Res. 18: 320-329.

Burdett, A.N. 1978. Root form and mechanical stability in planted lodgepole pine in British Columbia. pp. 162-165. In E. van Eerden and J.M. Kinghorn, eds. Proceedings of The Root Form of Planted Trees Symposium, May 16-19, 1978: Victoria, British Columbia. British Columbia Ministry of Forests/Canadian Forestry Service, Joint Report No. 8. 357 p.

Burdett, A.N. 1990. Physiological processes in plantation establishment and the development of specifications for forest planting stock. Can. J. For. Res. 20: 415-427.

Burdett, A.N. and P.A.F. Martin. 1982. Chemical root pruning of coniferous seedlings. Hortscience 17: 622-624.

Burdett, A.N., H. Coates, R. Erenko and P.A.F. Martin. 1986. Toppling in British Columbia's lodgepole pine plantations: significance, cause and prevention. For. Chron. 62: 433-439.

Butt, G. 1986. Plantation failure and backlog rehabilitation in the subboreal spruce and boreal black and white spruce zones in the northern interior of British Columbia: a problem analysis. British Columbia Ministry of Forests, Internal Report. Victoria, British Columbia. $129 \mathrm{p}$.

Butt, G. 1990. Forest regeneration in the ESSFa subzone: a problem analysis. British Columbia Ministry of Forests, FRDA Report No. 118. Victoria, British Columbia, $47 \mathrm{p}$.

Dong, H. and A.N. Burdett. 1986. Chemical root pruning of Chinese pine seedlings raised in cupric sulfide impregnated paper containers. New Forests 1: 67-73.

Eis, S. 1974. Root system morphology of western hemlock western red cedar and Douglas fir. Can. J. For. Res. 4: 28-38.

Eis, S. 1978. Natural root forms of western conifers. pp. 23-27. In E. van Eerden and J.M. Kinghorn., eds. Proceedings of the Root Form of Planted Trees Symposium May 16-19, 1978: Victoria, British Columbia. British Columbia Ministry of Forests/Canadian Forestry Service, Joint Report No. 8. 357 p.

Gessel, S.P. and A.N. Balci. 1963. Amount and composition of forest floors under Washington coniferous forests. pp. 11-24. In C.T. Youngberg, ed. Forest-Soil Relationships in North America. Oregon State University Press, Corvallis. 532 p.

Grene, S. 1978. Root deformations reduce root growth and stabili- 
ty. pp. 150-155. In E. van Eerden and J.M. Kinghorn, eds. Proceedings of the Root Form of Planted Trees Symposium May 16-19, 1978: Victoria, British Columbia. British Columbia Ministry of Forests/Canadian Forest Service, Joint Report No. 8. 357 p.

Halter, M.R. and C.P. Chanway. 1993. Growth and root morphology of planted and naturally-regenerated Douglas-fir and lodgepole pine. Ann. For. Sci. 50: 71-77.

Halter, M.R., C.P. Chanway and G.J. Harper. 1993. Growth reduction and root deformation of containerized lodgepole pine saplings 11 years after planting. For. Ecol. Manage. 56: 131-146.

Harvey, A.E., M.F. Jurgensen, M.J. Larsen and R.T. Graham. 1987. Relationships among soil microsite, ectomycorrhizae, and natural conifer regeneration of old-growth forests in western Montana. For. Ecol. Man. 12: $233-251$.

Heineman, J. 1991. Growth of interior spruce seedlings on forest floor materials. M.Sc. thesis. Department of Forest Sciences. University of British Columbia. 119 p.

Hunt, G.A. 1990. Effect of styroblock design and copper treatment on morphology of conifer seedlings. pp. 218-222. In R. Rose, S.J. Campbell and T.D. Landis, eds. In Target Seedling Symposium: Proceedings, Combined Meeting of the Western Forest Nursery Associations August 13-17, 1990; Roseburg, Oregon. Gen. Tech. Rep. RM-200. Ft. Collins, CO; U.S. Department of Agriculture, Forest Service, Rocky Mountain Forest and Range Experiment Station. 286 p.

Kimmins, J.P. and B.R. Hawkes. 1978. Distribution and chemistry of fine roots in a white spruce - subalpine fir stand in British Columbia: implications for management. Can. J. For. Res. 8: 265-279. Kinghorn, J.M. 1978. Minimizing potential root problems through container design. pp. 311-318. In E. van Eerden and J.M. Kinghorn, eds. Proceedings of The Root Form of Planted Trees Symposium, May 16-19, 1978: Victoria, British Columbia. British Columbia Ministry of Forests/Canadian Forest Service, Joint Report No. 8. 357 p.

Lopushinsky and Max. 1990. Effect of soil temperature on root and shoot growth and on budburst timing in conifer seedling transplants. New For. 4: 107-124.

McMinn, R.G. 1978. Root development of white spruce and lodgepole pine seedlings following outplanting. pp. 186-190. In E. van Eerden and J.M. Kinghorn, eds. Proceedings of the Root Form of Planted Trees Symposium May 16-19, 1978: Victoria, British Columbia. British Columbia Ministry of Forests/Canadian Forest Service, Joint Report No. 8.357 p.

Newton, M. and E.C. Cole. 1991. Root development in planted Douglasfir under varying competitive stress. Can. J. For. Res. 21: 25-31.
Örlander, G., P. Gemmel and J. Hunt. 1990. Site preparation: a Swedish overview. British Columbia Ministry of Forests, FRDA Report No. 105. Victoria, British Columbia. $62 \mathrm{p}$.

Owston, P.W. 1990. Target seedling specification: are stocktype designations useful? pp. 9-16. In R. Rose, S.J. Campbell and T.D. Landis, eds. Target Seedling Symposium: Proceedings, Combined Meeting of the Western Forest Nursery Associations August 13-17, 1990; Roseburg, Oregon. Gen. Tech. Rep. RM-200. Ft. Collins, CO; U.S. Department of Agriculture, Forest Service, Rocky Mountain Forest and Range Experiment Station. 286 p.

Planting Quality Inspection Manual F.S. 704. 1990. British Columbia Ministry of Forests, Victoria, British Columbia. $28 \mathrm{p}$.

Rose, R., W.C. Carlson and P. Morgan. 1990. The target seedling concept. pp. 1-8. In R. Rose, S.J. Campbell and T.D. Landis, eds. Target Seedling Symposium: Proceedings, Combined Meeting of the Western Forest Nursery Associations August 13-17, 1990: Roseburg, Oregon. Gen. Tech. Rep. RM-200. Ft. Collins, CO; U.S. Department of Agriculture, Forest Service, Rocky Mountain Forest and Range Experiment Station. 286 p.

Scagel, R. and R. Evans. 1992. Exploratory survey of Coastal Douglas-fir roots. Growth, form, and symmetry of stocktypes. British Columbia Ministry of Forests Silviculture Section, Vancouver Forest Region. 5 p.

Scagel, R., M. Madill and C. Kooistra. 1992. Seedling stock type selection and ordering guidelines: Nelson forest region. British Columbia Ministry of Forests (March). 54 p.

Selby, C. and D.A. Seaby. 1982. The effects of auxin on Pinus contorta seedling root development. Forestry 55: 125-135.

Stathers, R.J. and D.L. Spittlehouse. 1990. Forest soil temperature manual. British Columbia Ministry of Forests, FRDA Report 130. Victoria, British Columbia. $47 \mathrm{p}$.

Strong, W.L. and G.H. La Roi. 1985. Root density - soil relationships in selected boreal forests of central Alberta, Canada. For. Ecol. Man. 12: 233-251.

Turner, A. 1990. The Tree Planters Manual. Courtenay, British Columbia. 35 p.

van Eerden, E. and J.M. Kinghorn (eds.). 1978. Proceedings of the Root Form of Planted Trees Symposium May 16-19, 1978: Victoria, British Columbia. British Columbia Ministry of Forests/Canadian Forest Service, Joint Report No. 8. 357 p. 